\title{
Correction to: Assessment of individual tumor buds using keratin immunohistochemistry: moderate interobserver agreement suggests a role for machine learning
}

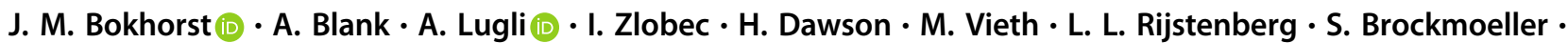 \\ M. Urbanowicz • J. F. Flejou • R. Kirsch · F. Ciompi · J. A. W. M. van der Laak (1) - I. D. Nagtegaal
}

Published online: 3 January 2020

(c) The Author(s) 2020. This article is published with open access

\section{Correction to: Modern Pathology}

https://doi.org/10.1038/s41379-019-0434-2

The article Assessment of individual tumor buds using keratin immunohistochemistry: moderate interobserver agreement suggests a role for machine learning, written by J. M. Bokhorst, A. Blank, A. Lugli, I. Zlobec, H. Dawson, M. Vieth, L. L. Rijstenberg, S. Brockmoeller, M. Urbanowicz, J. F. Flejou, R. Kirsch, F. Ciompi, J. A. W. M. van der Laak and I. D. Nagtegaal, was originally published electronically on the publisher's internet portal on $16^{\text {th }}$ December 2019 without open access. With the authors' decision to opt for Open Choice the copyright of the article changed on 3rd January 2020 to (C) The Author(s) 2019 and the article is forthwith distributed under a Creative Commons Attribution 4.0 International License (https://creativecommons. org/licenses/by/4.0/), which permits use, sharing, adaptation, distribution and reproduction in any medium or format, as long as you give appropriate credit to the original author(s) and the source, provide a link to the Creative Commons licence, and indicate if changes were made.

Open Access This article is licensed under a Creative Commons Attribution 4.0 International License, which permits use, sharing, adaptation, distribution and reproduction in any medium or format, as long as you give appropriate credit to the original author(s) and the source, provide a link to the Creative Commons license, and indicate if changes were made. The images or other third party material in this article are included in the article's Creative Commons license, unless indicated otherwise in a credit line to the material. If material is not included in the article's Creative Commons license and your intended use is not permitted by statutory regulation or exceeds the permitted use, you will need to obtain permission directly from the copyright holder. To view a copy of this license, visit http://creativecommons. org/licenses/by/4.0/. 